\title{
Precipitation of Trichoderma reesei commercial cellulase preparations under standard enzymatic hydrolysis conditions for lignocelluloses
}

\author{
Piotr Chylenski • Claus Felby • \\ Mai Østergaard Haven · Miguel Gama • \\ Michael J. Selig
}

Received: 5 December 2011/Accepted: 21 March 2012/Published online: 3 April 2012

(C) Springer Science+Business Media B.V. 2012

\begin{abstract}
Comparative studies between commercial Trichoderma reesei cellulase preparations show that, depending on the preparation and loading, total protein precipitation can be as high as $30 \%$ under standard hydrolysis conditions used for lignocellulosic materials. ATR-IR and SDS-PAGE data verify precipitates are protein-based and contain key cell wall hydrolyzing enzymes. Precipitation increased considerably with incubation temperature; roughly 50-150\% increase from 40 to $50{ }^{\circ} \mathrm{C}$ and $800 \%$ greater at $60{ }^{\circ} \mathrm{C}$. All of the reported protein losses translated into significant, and often drastic, losses in activity on related 4-nitrophenyl substrates. In addition, supplementation with the non-ionic surfactant PEG 6,000 decreased precipitation up to $80 \%$ in $24 \mathrm{~h}$ precipitation levels. Protein precipitation is potentially substantial during enzymatic hydrolysis of lignocelluloses and should be accounted for during lignocellulose conversion process design, particularly when enzyme recycling is considered.
\end{abstract}

P. Chylenski $(\varangle) \cdot$ C. Felby · M. J. Selig

Faculty of Science, University of Copenhagen,

Rolighedsvej 23, 1958 Frederiksberg C, Denmark

e-mail: pchyle@life.ku.dk

M. Østergaard Haven

Inbicon A/S, Kraftværksvej 53, 7000 Fredericia, Denmark

M. Gama

Department of Biological Engineering, University of

Minho, Campus de Gualtar, 4710-057 Braga, Portugal
Keywords Biofuels $\cdot$ Cellulase $\cdot$ Enzyme recycle $\cdot$ Lignocellulose $\cdot$ Precipitation

\section{Introduction}

Lignocellulose conversion research over the last thirty years has involved the development of processes to improve structural carbohydrate accessibility to a few specific fungal enzymatic degradation systems; the primary focus being extraction of fermentable sugars from the plant cell wall matrix. Cell wall-degrading enzymes from the filamentous fungus, Trichoderma reesei, are the most studied of these systems and the most integrated into technology development. The heavy reliance on a specific enzymatic system has significantly shaped the design of the conversion technologies as well as the investigation of the most cost-impacting process bottlenecks (Kohlmann et al. 1995; Himmel et al. 2007).

The high costs associated with the production of commercial cellulase preparations, coupled with constant pressure to reduce costs associated with lignocellulosic conversion processes, has driven efforts within the field aimed at reducing the quantity of enzymes utilized in processes. Efforts have included improvements to enzyme system efficiency via accessory enzyme supplementation, the improvement of specific workhorse enzyme efficiencies via coupled molecular simulations and protein engineering, and recently interest has gained in the recycle of enzymes 
following saccharification/fermentation processes (Selig et al. 2009; Adney et al. 2009; Tu et al. 2007, 2009; Qi et al. 2011).

Enzyme recycle research has often focused on issues associated with enzyme binding to process residuals that are often high in lignin (Yang and Wyman 2006). Something commonly overlooked in these studies is the potential for enzymatic proteins to precipitate out of solution during the conversion processes. Many lignocellulose-degrading enzymes are reasonably-sized proteins with MW from 20,000 to 120,000 Da, and are characterized by numerous hydrophobic regions making aggregation into large insoluble complexes probable (Vinzant et al. 2001). In addition, we have noted during years of routine laboratory testing that commercial T. reesei cellulase preparations form precipitates once diluted for use in bench-scale hydrolysis experiments; this has also been observed by others although never given the attention worthy of a publication (personal communication; Stephen R. Decker, National Renewable Energy Laboratory, Golden, Colorado, United States).

This paper addresses the hypothesis that significant portions of the protein in commercial enzyme preparations may simply precipitate out of solution and become inactive and unrecoverable under traditional lignocellulose hydrolysis conditions. The occurrence of protein precipitation at standard hydrolysis conditions was assessed and quantified for a selection of the most commonly studied commercial $T$. reesei cellulase preparations. The presence of protein in the precipitates was verified via Attenuated Total Reflectance Fourier Transform Infrared (ATR-FTIR) spectroscopy and SDSPAGE was used to qualitatively predict the enzyme types most susceptible to precipitation. In addition, reductions in lignocellulose degrading activities associated with the precipitation effects were comparatively measured. The effects of temperature and the addition of a non-ionic surfactant were also assessed. The data presented will be of value to researchers interested in enzyme recycle options and general cost optimization for lignocellulosic conversion processes.

\section{Materials and methods}

Protein precipitation studies

Four commercial $T$. reesei cellulase preparations were assessed for potential precipitation effects upon dilution; for anonymity they have been labeled cellulase preparation A, B, C, and D. All cellulase preparations were tested at $50{ }^{\circ} \mathrm{C}$. Expanded investigations at room temperature, 40 and $60{ }^{\circ} \mathrm{C}$ were conducted with preparation $\mathrm{A}$ by itself and supplemented with a commercial Aspergillus niger $\beta$-glucosidase preparation; addition of a non-ionic surfactant (PEG 6000 at $0.05 \%$ (w/v); Merck KGaA, Darmstadt, Germany) on precipitation levels was tested; all expanded investigations were only incubated for $24 \mathrm{~h}$. Dilutions of 10 and $1 \mathrm{mg} / \mathrm{ml}$ into $50 \mathrm{mM}$ sodium citrate buffer, $\mathrm{pH} 4.8$, were tested. Diluted enzymes were filtered through $0.22 \mu \mathrm{m}$ polyethersulfone (PES) filters to remove precipitated protein; the filters were chosen for their low capacity to bind protein (Mahler et al. 2010). All dilutions were incubated in $10 \mathrm{ml}$ aliquots in $15 \mathrm{ml}$ conical tubes. All experiments were run under static conditions. Whole replicate vials were sampled for analysis at 24 and $120 \mathrm{~h} ; 1 \mathrm{ml}$ samples were filtered through $0.22 \mu \mathrm{m}$ PES filters. Precipitates were separated by centrifugation for $15 \mathrm{~min}$ at $(4,200 \times g)$ and $4{ }^{\circ} \mathrm{C}$. Separated supernatants and precipitates where stored at $-20{ }^{\circ} \mathrm{C}$ for further analysis.

\section{Protein assays}

Protein concentrations in all presented experiments were obtained using the BCA Protein Assay Kit (Pierce). The only modification to the kit protocol for micro-plates was the absorbance was measured at $570 \mathrm{~nm}$ in a microplate reader.

\section{Enzyme activity assays}

The lignocellulosic related enzymatic activities in the diluted enzyme preparation was assessed by measuring activity on 4-nitrophenyl substrates as described by Wood and Bhat (1988). $\beta$-Glucosidase and $\beta$-xylosidase activities were measured with $5 \mathrm{mM}$ 4-nitrophenyl- $\beta$-D-glucopyranoside (4-NPG) and 4-nitrophenyl- $\beta$-D-xylopyranoside (4-NPX), respectively. Activity related to key cellulase activities in preparations was determined using $2 \mathrm{mM}$ 4-nitrophenyl- $\beta$-D-lactopyranoside (4-NPLac) as a substrate. Activity assays were run only on the $1 \mathrm{mg} / \mathrm{ml}$ solutions appropriately diluted to fit the assays working detection ranges. Assays were run for $15 \mathrm{~min}$ at $50{ }^{\circ} \mathrm{C}$ in $50 \mathrm{mM}$ sodium citrate buffer and stopped 
with $0.4 \mathrm{M}$ glycine buffer; absorbance was then measured at $405 \mathrm{~nm}$.

\section{Protein distribution via SDS-PAGE}

The molecular weight distribution in the supernatants and precipitates was assessed using SDS-PAGE with the Gel Doc EZ Imager (Bio-Rad 170-8270, USA) as described by Varnai et al. (2011). Electrophoresis was run at $200 \mathrm{~V}$ for approx. $50 \mathrm{~min}$ in $25 \mathrm{mM}$ Tris/ $192 \mathrm{mM}$ glycine/0.1 M SDS buffer. The Bio-Rad Precision Plus Unstained standard was used as a protein marker. The gels were visualized using a $5 \mathrm{~min}$ activation step and exposure step within the time range of $0.3-0.5 \mathrm{~s}$. For precipitated protein, a representative sample of pellet was resuspended in $50 \mathrm{mM}$ citrate/ $\mathrm{NaOH}$ buffer, $\mathrm{pH} 4.8$ and analyzed as described above.

\section{ATR-FTIR spectroscopy}

The pelletized precipitates from cellulase preparation A were analyzed on a Nicolet 6700 FT-IR spectrometer equipped with a temperature adjustable ATR (Golden Gate) component and purged with dry air. Pellets were oven-dried at $105{ }^{\circ} \mathrm{C}$ for roughly $1 \mathrm{~h}$ prior to ATR-IR analysis. The separate and distinct brown and white fractions were separated with a razor blade and analyzed separately. Spectra were collected at $4 \mathrm{~cm}^{-1}$ resolution after 100 scans; the background baseline was collected after 200 scans. Distortion associated with dispersion effects on IR band positions was corrected for by applying the advanced ATR correction in the spectrometer Omnic software. Five replicate spectra were taken of each pellet. Bovine serum albumin (BSA) was run as a general protein reference standard. The standard normal variate transformation as described by Barnes and co-authors (1989) was applied to all replicate spectra; an average of all transformed replicates is presented (Fig. 1).

\section{Results and discussion}

Initial experiments $\left(50{ }^{\circ} \mathrm{C}, \mathrm{pH} 4.8\right)$ with preparation $\mathrm{A}$ showed approx. 5-30 \% of the total protein precipitated from dilutions; this was complimented with noticeable decreases in 4-NPG, 4-NPX, and up to $20 \%$ losses in 4-NPLac activity after $120 \mathrm{~h}$. Precipitates from the preparations formed pellets consisting of two separate layers; a more dense white pellet and a voluminous cream to light brown colored pellet (dark brown for the substituted preparation A); the latter took the most time to settle. After separation and drying the two distinct pellets were analyzed via ATRIR spectroscopy to obtain an assessment of which pellet was the primary protein containing pellet; BSA was used as a protein reference. The spectra in Fig. 1 show the strongest similarity between the BSA reference and the brown pellet. Similar amide related peaks near wavenumbers $1,650 \mathrm{~cm}^{-1}(\mathrm{C}=\mathrm{O}$ stretching) and 1,540 $\mathrm{cm}^{-1}$ (CN stretching, and $\mathrm{NH}$ bending), bands around $1,400 \mathrm{~cm}^{-1}$ (C-O stretching of amino acid side chains), and similar peaks associated with $\mathrm{NH}$ bending at $3,300 \mathrm{~cm}^{-1}$ indicate the light brown pellet is the most protein dominant of the two pellets (Kong and Yu 2007). Both the light brown and white fractions do share spectral similarities, particularly between 1,150 and $900 \mathrm{~cm}^{-1}$, and the white pellet data do show some faint protein related peaks; this overlap can be easily explained by the fact that separation by sedimentation is not completely distinct and likely enabled some cross-contamination of the fractions. Despite this, it is clear from Fig. 1 that the dominant protein fraction is the less dense light brown pellet; this sentiment is reinforced by SDS-PAGE (Fig. 1b) of each fraction showing the brown pellet having distinct protein bands while no bands are present with respect to the white fraction.

Following up, enzyme preparation $\mathrm{A}$ and three other commercially available enzyme preparations were subjected to comparative study at two process and experimentally relevant dilution levels $(1 \mathrm{mg} / \mathrm{ml}$ and $10 \mathrm{mg} / \mathrm{ml}$ ). In Fig. 2 protein precipitation for each is assessed at 24 and $120 \mathrm{~h}$ compared to that of the initial filtered starting dilution. The data show significant variation in potential precipitation exists depending on the chosen cellulase preparation. In addition, it is clear that B-glucosidase supplementation of commercial preparation A had a significant impact on precipitation levels; although this impact is not as drastic once we consider the activity data presented in Tables 1a-c. Here both preparation A and the supplemented A show similar declines in activity, and actually a lesser decline in 4-NPG activity; this last point is likely due to the high thermostability of the A. niger preparation. The result suggests that much of the additional protein precipitated here could probably be referred to as "junk protein" that is not needed for 
Fig. 1 a FTIR spectra of the cloudy light brown and dense white fractions from pelletized precipitate of commercial enzyme preparation A. Spectra for bovine serum albumin (BSA) are provided as a protein reference. Data are presented as the standard normal variate transformations of average signals from five replicate measurements; b SDS-

PAGE of precipitated pellet fractions; lanes are as follows: (1) protein standard, (2) dilution A with ß-glucosidase, (3) light brown precipitate, and (4) white precipitate
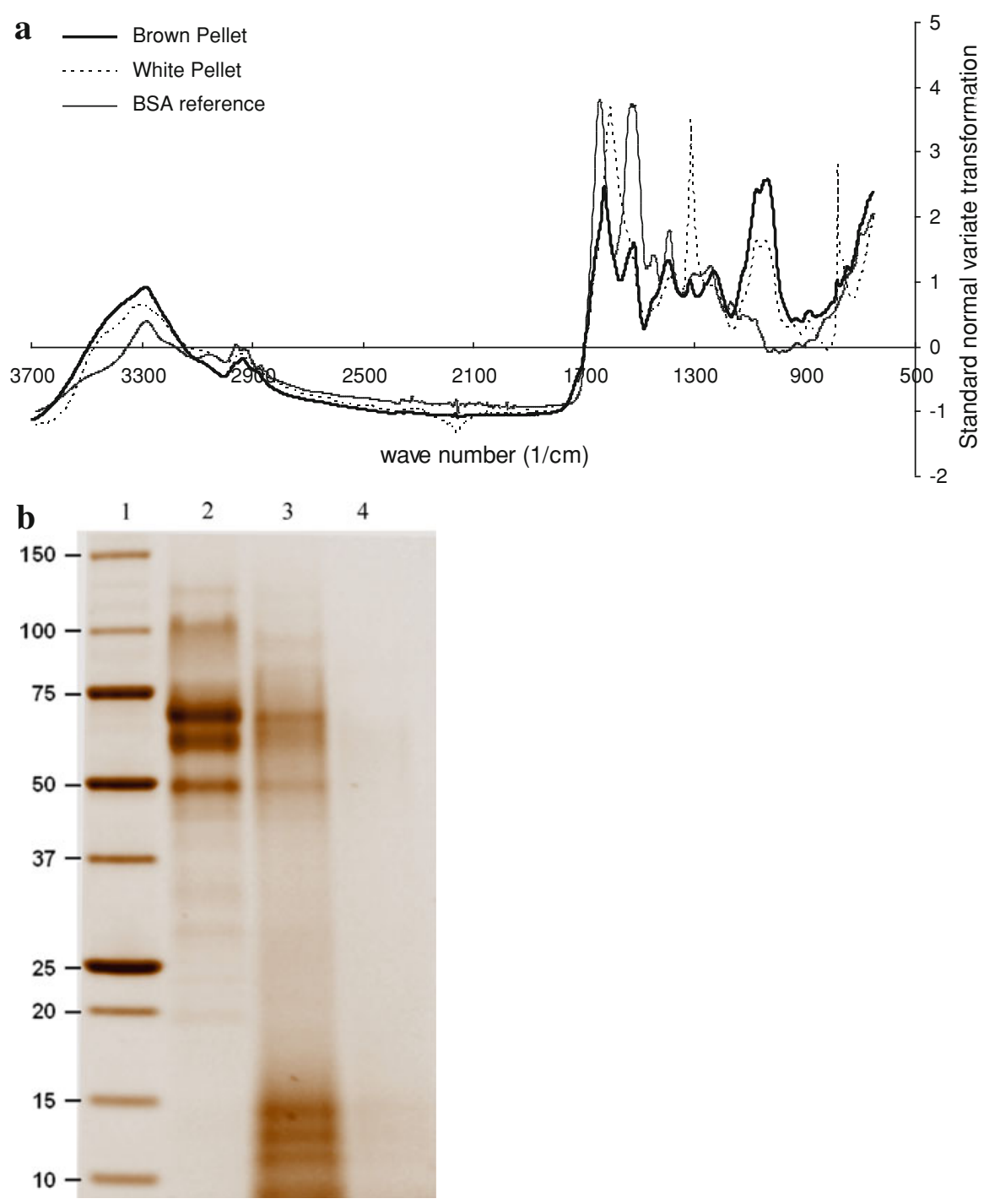

the effective enzymatic performance. Despite this, high rates of precipitation in the remaining preparations do correlate well with significant decreases in catalytic activity of the dilutions. Overall the activity data strongly suggest considerable amounts of protein precipitating from the enzyme preparations is active lignocellulosic hydrolyzing enzyme.

In Fig. 3 SDS-PAGE of the diluted enzyme preparations showed characteristic bands that either diminished or even vanished completely following the incubation/precipitation experiments. Of particular importance were bands between 50,000 and $75,000 \mathrm{Da}$; all bands in this region appear slightly diminished in the supernatant and are visible in the pellet fraction. Bands in this region are often associated with cellulase enzymes such as cellobiohydrolase I and II, and additionally endoglucanase I and II (Vinzant et al. 2001). Bands just below 25,000 and 20,000 Da vanished completely in many of the preparations; these are possibly associated with endoxylanase proteins. Additionally protein marked by bands above 100,000 Da contribute to the precipitate; B-glucosidase enzymes most typically fall into this high molecular weight range.

The compilation of missing protein bands observed in all of the $T$. reesei preparations is potentially representative of the entirety of key enzyme activities needed to effectively hydrolyze lignocellulosic materials; if these proteins contribute significantly to total precipitates it suggests even higher percentages of 
Fig. 2 Percentage of protein precipitated from multiple commercial cellulase preparations under standard hydrolysis conditions at $50{ }^{\circ} \mathrm{C}$; calculated from protein concentrations determined by Pierce BCA protein assay; error bars represent standard deviations of replicate analyses

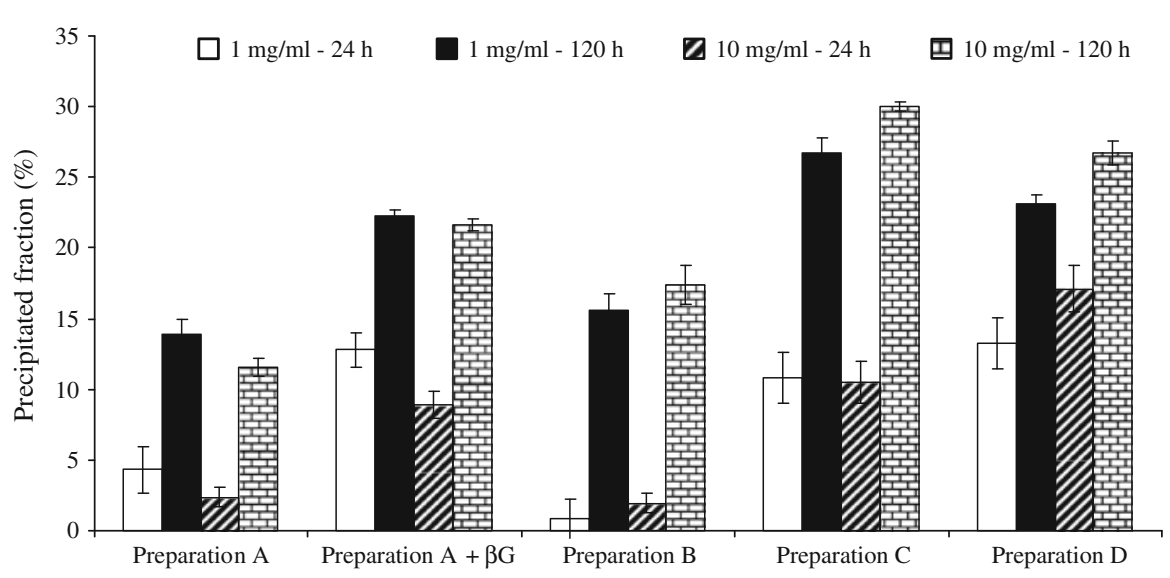

Table 1 Activity of cellulase preparations on 4-nitrophenyl substrates following dilution and incubation

\begin{tabular}{|c|c|c|c|c|c|c|c|c|c|}
\hline \multirow{2}{*}{$\begin{array}{l}\text { Enzyme } \\
\text { stock }^{\mathrm{a}}\end{array}$} & \multicolumn{3}{|c|}{ 4-nitrophenyl- $\beta$-D-glucopyranoside } & \multicolumn{3}{|c|}{ 4-nitrophenyl- $\beta$-D-xylopyranoside } & \multicolumn{3}{|c|}{ 4-nitrophenyl- $\beta$-D-lactopyranoside } \\
\hline & $0 \mathrm{~h}$ & $24 \mathrm{~h}$ & $120 \mathrm{~h}$ & $0 \mathrm{~h}$ & $24 \mathrm{~h}$ & $120 \mathrm{~h}$ & $0 \mathrm{~h}$ & $24 \mathrm{~h}$ & $120 \mathrm{~h}$ \\
\hline A & $2.5 \pm 0.1^{\mathrm{b}}$ & $2.5 \pm 0.2$ & $2.2 \pm 0.0$ & $3.6 \pm 0.1$ & $3.5 \pm 0.1$ & $3.1 \pm 0.0$ & $3.3 \pm 0.2$ & $3.2 \pm 0.1$ & $2.8 \pm 0.0$ \\
\hline $\mathrm{A}+\beta \mathrm{G}^{\mathrm{c}}$ & $6.4 \pm 0.4$ & $6.4 \pm 0.6$ & $6.3 \pm 0.3$ & $2.5 \pm 0.1$ & $2.3 \pm 0.1$ & $2.3 \pm 0$ & $2.2 \pm 0.1$ & $1.8 \pm 0.1$ & $1.8 \pm 0.1$ \\
\hline $\mathrm{B}$ & $8.6 \pm 0.3$ & $7.1 \pm 0.3$ & $6.1 \pm 0.3$ & $3.7 \pm 0.2$ & $2.9 \pm 0.1$ & $2.0 \pm 0.1$ & $3.0 \pm 0.1$ & $2.5 \pm 0.1$ & $2.1 \pm 0.1$ \\
\hline $\mathrm{C}$ & 2.5 & 1 & 8 & 3 & $2.2=$ & 1. & 1 & .1 & $1.2 \pm 0$ \\
\hline $\mathrm{D}$ & $87.2 \pm 15.5$ & $59.7 \pm 5.7$ & $34.6 \pm 8.6$ & $6.4 \pm 0.4$ & $4.7 \pm 0.2$ & $3.9 \pm 0.1$ & $1.9 \pm 0.2$ & $1.3 \pm 0.1$ & $1.2 \pm 0.1$ \\
\hline
\end{tabular}

${ }^{a}$ Cellulase commercial preparations from Trichoderma reesei (labeled A, B, C and D) diluted to $1 \mathrm{mg}$ protein/ml incubated at standard conditions for enzymatic hydrolysis of lignocelluloses $\left(50{ }^{\circ} \mathrm{C}\right.$; $\left.\mathrm{pH} 4.8\right)$ for $120 \mathrm{~h}$. Activity was assessed on $5 \mathrm{mM}$ 4-nitrophenyl- $\beta$-D-glucopyranoside, $5 \mathrm{mM}$ 4-nitrophenyl- $\beta$-D-xylopyranoside, and $2 \mathrm{mM}$ 4-nitrophenyl- $\beta$-D-lactopyranoside in $50 \mathrm{mM}$ sodium citrate buffer, $\mathrm{pH} 4.8$

b Activity is expressed as the amount of 4-nitrophenol $(\mu \mathrm{mol})$ released from substrate solutions per ml of diluted enzyme preparation after the 15 min assay

c $\beta$-glucosidase from Aspergillus niger

effective cellulase/hemicellulase protein are lost than what is reported in Fig. 2. That said, it is known that lignocellulose hydrolysis slows considerably after $24 \mathrm{~h}$, and long before complete saccharification is achieved. Above traditional arguments regarding the recalcitrant nature of lignocellulosic biomass, we should now consider that overall hydrolysis rates simply slow down because large fractions of active protein fall out of solution; this argument is certainly reinforced by the declines in activity observed in Table 1.

Expanded studies on to preparation A looked into the effects of temperature and the addition of a nonionic surfactant; preparation A and supplemented A were tested. In Fig. 4 a significant increase in precipitation begins somewhere between the 40 and the $50{ }^{\circ} \mathrm{C}$. Increases over 800 and $150 \%$ respectively were observed for preparation A and the supplemented
A when incubation was performed at $60{ }^{\circ} \mathrm{C}$. Activities on the tested 4-nitrophenol substrates declined in a similar fashion within the same temperature ranges, suggesting a correlation between the two (Fig. 4). SDS-PAGE (Fig. 5) show how significant the loss of protein is between 50 and $60{ }^{\circ} \mathrm{C}$, particularly with respect to proteins in the range of 50-70,000 Da. In addition, SDS-PAGE of the precipitate (not shown) indicated much of the protein precipitated at $60{ }^{\circ} \mathrm{C}$ had degraded into low molecular weight fractions below 20,000 Da. Overall, this data is supported by temperature stability studies on the most prominent cellulase from $T$. reesei, Cel7A, showing enzyme deactivation at temperature just above the standard hydrolysis temperature of $50{ }^{\circ} \mathrm{C}$ (Hall et al. 2011). It suggests consideration of slightly lower hydrolysis temperatures $\left(45-48{ }^{\circ} \mathrm{C}\right)$ may preserve much of the enzymatic preparation for later stages of hydrolysis. 


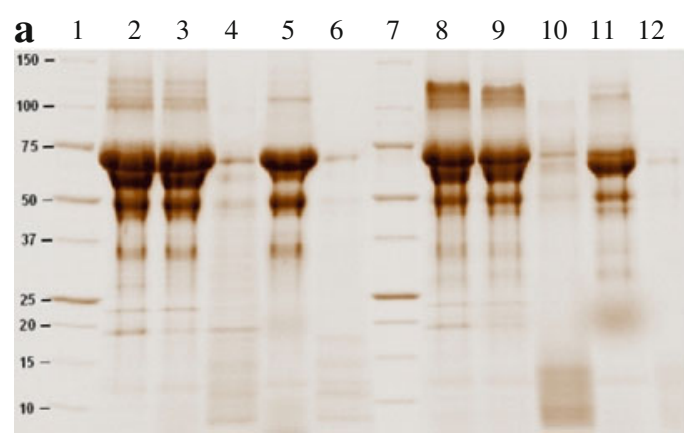

Fig. 3 a SDS-PAGE of commercial preparation A dilution supernatants and pellets following incubation at $50{ }^{\circ} \mathrm{C}$; lanes are as follows: (1) protein standard, (2) preparation A at $0 \mathrm{~h}$, (3) A supernatant at $24 \mathrm{~h},(4)$ A pellet at $24 \mathrm{~h},(5)$ A supernatant at $120 \mathrm{~h},(6)$ A pellet at $120 \mathrm{~h},(7)$ protein standard, (8) preparation A supplemented with $\beta$-glucosidase $(\mathrm{A}+\beta \mathrm{G})$ at $0 \mathrm{~h},(9) \mathrm{A}+\beta \mathrm{G}$ supernatant at $24 \mathrm{~h},(10) \mathrm{A}+\beta \mathrm{G}$ pellet $24 \mathrm{~h},(11) \mathrm{A}+\beta \mathrm{G}$ supernatant $120 \mathrm{~h},(12) \mathrm{A}+\beta \mathrm{G}$ pellet $120 \mathrm{~h}$; b SDS-PAGE of

Currently, the addition of small amounts of surfactant to the hydrolysis environment in known to be beneficial (Kristensen et al. 2007). Hypotheses revolving around this suggest surfactants sufficiently change the aqueous environment reducing the level of non-productive binding to insoluble substrates such as hydrophobic lignins (Yang and Wyman 2006). In

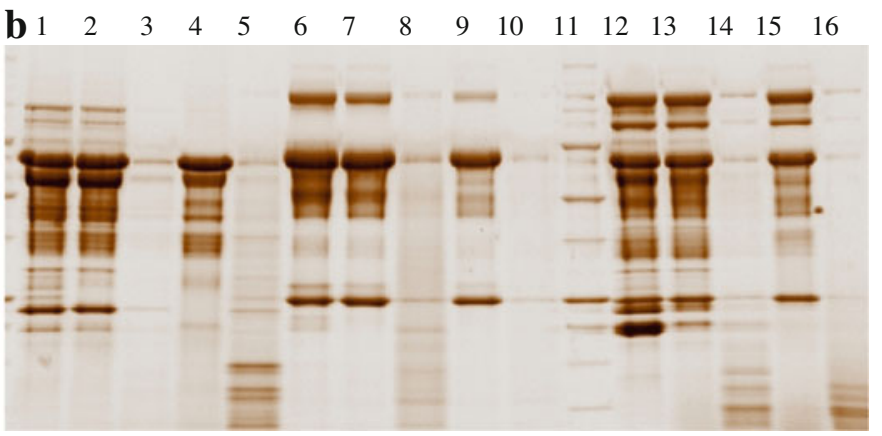

commercial preparations B through D dilution supernatants and pellets following incubation at $50{ }^{\circ} \mathrm{C}$; lanes are as follows: (1) preparation B at $0 \mathrm{~h},(2) \mathrm{B}$ supernatant at $24 \mathrm{~h}$, (3) B pellet at $24 \mathrm{~h}$, (4) B supernatant at $120 \mathrm{~h}$, (5) B pellet at $120 \mathrm{~h}$, (6) preparation $\mathrm{C}$ at $0 \mathrm{~h},(7) \mathrm{C}$ supernatant at $24 \mathrm{~h},(8) \mathrm{C}$ pellet $24 \mathrm{~h}$, (9) C supernatant $120 \mathrm{~h}$, (10) C pellet $120 \mathrm{~h}$, (11) protein standard, (12) preparation D at $0 \mathrm{~h},(13) \mathrm{D}$ supernatant at $24 \mathrm{~h}$, (14) D pellet $24 \mathrm{~h},(15) \mathrm{D}$ supernatant $120 \mathrm{~h},(16) \mathrm{D}$ pellet $120 \mathrm{~h}$

Table 2 the addition of PEG 6000 considerably reduced protein precipitation at $50{ }^{\circ} \mathrm{C}$; over an $80 \%$ reduction in precipitation after $24 \mathrm{~h}$ with cellulase preparation A was observed. This observation suggests that a significant portion of previously reported mitigation of non-productive binding to lignocelluloses by the addition of PEG may simply be the result

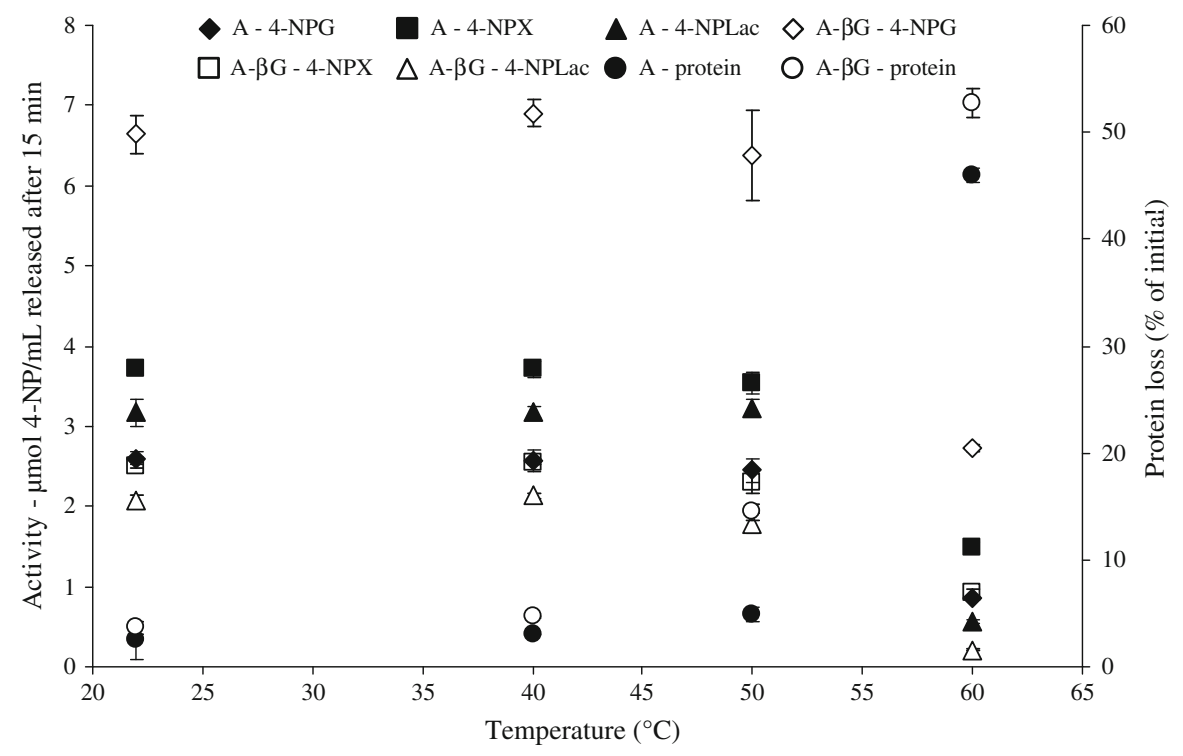

Fig. 4 Percentage of protein precipitated from commercial cellulase preparation A and preparation A supplemented with additional $\beta$-glucosidase as calculated from protein concentrations determined by Pierce BCA protein assay and activity on 4-nitrophenol substrates at room temperature, 40,50 and $60{ }^{\circ} \mathrm{C}$; activity is expressed as the amount of 4-nitrophenol ( $\mu \mathrm{mol})$ released from substrate solutions per $\mathrm{ml}$ of diluted enzyme preparation ( $1 \mathrm{mg}$ protein/ml initially) after the $15 \mathrm{~min}$ incubation; error bars represent standard deviations of replicate analyses 


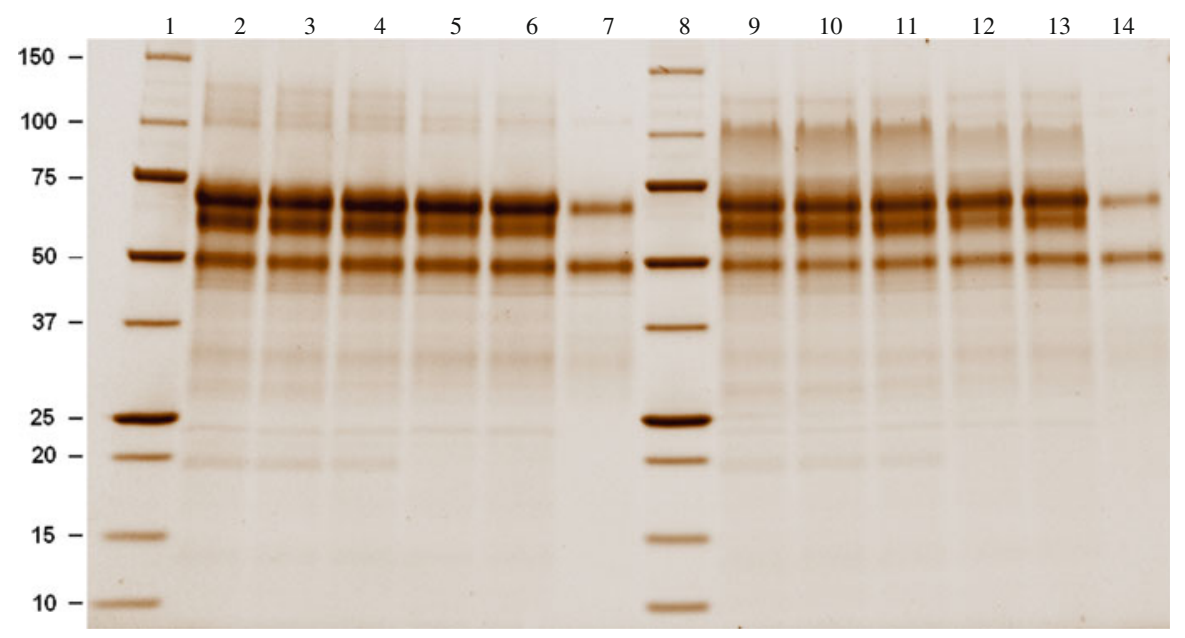

Fig. 5 SDS-PAGE of commercial enzyme preparation A liquid fraction at room temperature, 40,50 and $60{ }^{\circ} \mathrm{C}$ as well as $50^{\circ} \mathrm{C}$ in the presence of $0.05 \%$ PEG 6000; (1) protein standard, (2) preparation $\mathrm{A}$ at $0 \mathrm{~h}$, (3) A supernatant after $24 \mathrm{~h}$ at room temperature, (4) A supernatant after $24 \mathrm{~h}$ at $40{ }^{\circ} \mathrm{C}$, (5) A supernatant after $24 \mathrm{~h}$ at $50{ }^{\circ} \mathrm{C},(6) \mathrm{A}$ supernatant after $24 \mathrm{~h}$ at $50{ }^{\circ} \mathrm{C}$ with PEG 6000, (7) A supernatant after $24 \mathrm{~h}$ at $60{ }^{\circ} \mathrm{C},(8)$

Table 2 Percentage of protein precipitated from diluted cellulase preparation A with and without addition of PEG 6000

\begin{tabular}{lrr}
\hline Enzyme stock & \multicolumn{1}{c}{$50{ }^{\circ} \mathrm{C}$} & + PEG 6000 \\
\hline $\mathrm{A}$ & $5 \pm 0.7^{\mathrm{b}}$ & $0.8 \pm 0.6$ \\
$\mathrm{~A}+\beta \mathrm{G}$ & $14.5 \pm 0.7$ & $11.3 \pm 1.6$ \\
\hline
\end{tabular}

${ }^{a}$ Precipitated fraction (\% of original) of commercial cellulase preparation $\mathrm{A}$ and $\mathrm{A}$ supplemented with commercial $\beta$ glucosidase diluted to $10 \mathrm{mg} / \mathrm{ml}$ and incubated at standard conditions for enzymatic hydrolysis of lignocelluloses $\left(50{ }^{\circ} \mathrm{C}\right.$, $\mathrm{pH} 4.8$ ) for $24 \mathrm{~h}$

b Protein concentrations were determined by BCA assay

of reduced enzyme precipitation. Despite this, nonproductive enzyme binding does likely happen, but we should note there are significant difficulties associated delineating whether protein has remained soluble, and bound non-productively, or has simply precipitated onto the insoluble substrates. The development of an intricate method to distinguish between the two occurrences would be a valuable endeavor in this case.

Acknowledgments This work was supported by the project "Demonstrating Industrial scale second generation bioethaol production-Kalundborg Cellulosic Ethanol Plant" under the EU FP7 framework program and the project "Development of improved second generation (2G) bioethanol technology to protein standard, (9) preparation A supplemented with Bglucosidase $(\mathrm{A}+\beta \mathrm{G})$ at $0 \mathrm{~h},(10) \mathrm{A}+\beta \mathrm{G}$ supernatant after $24 \mathrm{~h}$ at room temperature, (11) $\mathrm{A}+\beta \mathrm{G}$ supernatant after $24 \mathrm{~h}$ at $40{ }^{\circ} \mathrm{C}$, (12) $\mathrm{A}+\beta \mathrm{G}$ supernatant after $24 \mathrm{~h}$ at $50{ }^{\circ} \mathrm{C},(13) \mathrm{A}+\beta \mathrm{G}$ supernatant after $24 \mathrm{~h}$ at $50{ }^{\circ} \mathrm{C}$ with PEG 6000, (14) A+ $\beta \mathrm{G}$ supernatant after $24 \mathrm{~h}$ at $60{ }^{\circ} \mathrm{C}$

prepare for commercialization under the Danish Energy Technology and Demonstration Programme (EUDP).

\section{References}

Adney WS, Jeoh T, Beckham GT, Chou YC, Baker JO, Michener W, Brunecky R, Himmel ME (2009) Probing the role of N-linked glycans in the stability and activity of fungal cellobiohydrolases by mutational analysis. Cellulose 16(4):699-709

Barnes RJ, Dhanoa MS, Lister SJ (1989) Standard normal variate transformation and de-trending of near-infrared diffuse reflectance spectra. Appl Spectrosc 43(5):772-777

Hall M, Rubin J, Behrens SH, Bommarius AS (2011) The cellulose-binding domain of cellobiohydrolase Cel7A from Trichoderma reesei is also a thermostabilizing domain. J Biotechnol 155(4):370-376

Himmel ME, Ding SY, Johnson DK, Adney WS, Nimlos MR, Brady JW, Foust TD (2007) Biomass recalcitrance: engineering plants and enzymes for biofuels production. Science 315:804-807

Kohlmann KL, Westgate P, Velayudhan A, Weil J, Sarikaya A, Brewer MA, Hendrickson RL, Ladisch MR (1995) Enzyme conversion of lignocellulosic plant materials for resource recovery in a controlled ecological life support system. Adv Space Res 18:251-265

Kong J, Yu S (2007) Fourier transform infrared spectroscopic analysis of protein secondary structures. Acta Biochim Biophys Sin 39(8):549-559

Kristensen JB, Borjesson J, Bruun MH, Tjerneld F, Jørgensen H (2007) Use of surface active additives in enzymatic 
hydrolysis of wheat straw lignocellulose. Enzym Microb Technol 40:888-895

Mahler HC, Huber F, Kishore RSK, Reindl J, Ruckert P, Muller $\mathrm{R}$ (2010) Adsorption behavior of a surfactant and a monoclonal antibody to sterilizing-grade. J Pharma Sci 99: 2620-2627

Qi B, Chen X, Su Y, Wan Y (2011) Enzyme adsorption and recycling during hydrolysis of wheat straw lignocellulose. Biores Technol 102:2881-2889

Randolph TW, Jones LS (2002) Surfactant-protein interactions. In: Carpenter JF, Manning MC (eds) Rational design of stable protein formulations. Kluwer/Plenum, New York, pp 159-175

Selig MJ, Adney WS, Himmel ME, Decker SR (2009) The impact of cell wall acetylation on corn stover hydrolysis by cellulolytic and xylanolytic enzymes. Cellulose 16:711-722

Tu M, Chandra RP, Saddler JN (2007) Recycling cellulases during the hydrolysis of steam exploded and ethanol pretreated lodgepole pine. Biotechnol Prog 23:1130-1137
Tu M, Zhang X, Paice M, MacFarlane P, Saddler J (2009) The potential of enzyme recycling during the hydrolysis of a mixed softwood feedstock. Biores Technol 100:6407-6415

Varnai A, Viikari L, Marjamaa K, Siika-aho M (2011) Adsorption of monocomponent enzymes in enzyme mixture analyzed quantitatively during hydrolysis of lignocellulose substrates. Biores Technol 102:1220-1227

Vinzant TB, Adney WS, Decker SR, Baker JO, Kinter MT, Sherman NE, Fox JW, Himmel ME (2001) Fingerprinting Trichoderma reese $i$ hydrolases in a commercial cellulase preparation. Appl Biochem Biotechnol 91-93:99-107

Wood TM, Bhat KM (1988) Methods for measuring cellulase activities. Method Enzymol 160:87-112

Yang B, Wyman C (2006) BSA treatment to enhance enzymatic hydrolysis of cellulose in lignin containing substrate. Biotechnol Bioeng 94:611-617 